\title{
Clinical significance of promoter hypermethylation of genes in ovarian cancer
}

\author{
Xinxin Zhu ${ }^{1,2}$ and Jinghe Lang ${ }^{1}$ \\ ${ }^{1}$ Department of Obstetrics and Gynecology, Peking Union Medical College Hospital, Peking Union Medical College, Chinese \\ Academy of Medical Sciences, Beijing, China \\ ${ }^{2}$ Department of Obstetrics and Gynecology, Institute for Wound Research, University of Florida, Gainesville, Florida, USA \\ Correspondence to: Jinghe Lang, email: langjh@hotmail.com, doctorlangjh@163.com \\ Keywords: epigenetic; DNA methylation; gene silencing; immunotherapy; ovarian cancer
}

Received: August 02, $2017 \quad$ Accepted: December 18, $2017 \quad$ Published: December 29, 2017

Copyright: Zhu et al. This is an open-access article distributed under the terms of the Creative Commons Attribution License 3.0 ( $C$ C BY 3.0), which permits unrestricted use, distribution, and reproduction in any medium, provided the original author and source are credited.

\section{ABSTRACT}

Ovarian cancer is the most lethal condition in gynecologic oncology. The known prognostic factors for ovarian cancer include tumor stage, histological grade, lymph node, and distant metastasis; however, handy and reliable molecular biomarkers for prevention, diagnosis, personalized treatment, and prognosis are scarce. Despite histological differences, the clinical treatment strategy is similar for ovarian cancers. The survival rate for ovarian cancer, however, remains relatively low. Accumulating evidence suggests that hypermethylated promoters of genes can be promising candidates as molecular biomarkers in ovarian cancer risk evaluation, early detection, personalized treatment, and prognosis. With advancements in immunology, hypermethylation of gene promoters was found to alter the tumor immune microenvironment, and gene methyltransferase inhibitors can contribute to ovarian cancer immunotherapy by boosting tumor immunogenicity and immune response and decreasing immunosuppression. Although DNMTis demonstrate high efficacy in hematologic malignancies, the application of DNMTis in solid tumors is just in its beginning. This article, drawing on both preclinical and clinical data, systematically reviews the common hypermethylated genes in ovarian cancer and their clinical applications, evaluating their usefulness in early diagnosis, personalized treatment, prognosis prediction, and the establishment of combined therapy of methyltransferase inhibitors and immunotherapy.

\section{INTRODUCTION}

Ovarian cancer (OC) is one of most lethal gynecological malignancies in women, with an estimated 238,700 new cases and more than 150,000 deaths in 2012 worldwide [1]. The high lethality of OC is mainly attributed to the lack of early detection strategies and to nonspecific symptoms that cause most patients to be diagnosed only at an advanced stage (International Federation of Gynecology and Obstetrics III-IV stage). The standard first-line treatment for $\mathrm{OC}$ is debulking surgery and platinum/ taxane-based chemotherapy [2], which is curative in up to $90 \%$ of patients with early stage OC. The 5 -year overall survival rate after the initial diagnosis in these patients is more than $70 \%$. However, this rate sharply decreases to less than $30 \%$ for those with advanced-stage OC $[3,4]$. The short of early screen biomarkers and the development of chemotherapeutic resistance are main obstacles to effective therapies. Therefore, early detection, and individualized treatment are imperative to improve the outcome for patients with advanced-stage OC.

The accumulation of genomic mutations has long been considered to be the core driver of tumorigenesis and progression [5]. With the developments in epigenetics, it has been confirmed that genetic mutation alone cannot account for the complexity of malignant tumors; epigenetic changes also play influential roles in the abnormal events of cancers, including OC [6-9]. 
The aberrant epigenetic alteration can lead to tumor formation and development, rendering the understanding and inhibition of these mechanisms essential. Unlike the nearly irreversible gene mutations, the epigenetic alterations are potentially reversible which make them attracting and promising biomarkers to prevent or treat $\mathrm{OC}$ [10]. In this systematic review, we discuss the common genes currently known to be silenced by hypermethylation in OC; investigate whether these methylated genes can serve as the biomarkers for early diagnosis, individualized treatment, therapeutic response, and prognosis evaluation; and explore the possibilities for combined cancer therapy comprising deoxyribonucleic acid (DNA) methyltransferase (DNMT) and immunotherapy.

\section{DNA HYPERMETHYLATION}

Conrad Waddington first proposed the concept of epigenetics in 1942 [11]. Epigenetic events lead to heritable modifications in gene expression other than the changes in DNA nucleotide sequences [12-14]. A relation between aberrant DNA methylation and human cancers was first reported in 1983 [15]. Since then, numerous studies have investigated its role in tumorigenesis, progression, and prognosis. Approximately 70\% of human gene promoters feature cytosine guanine $(\mathrm{CpG})$ rich sequences (CpG loci) [16]. Compared with the bulk of DNA, the $\mathrm{CpG}$ loci within genes promoters are often methylation-free, which is a prerequisite for normal gene transcription $[10,17,18]$.

DNA hypermethylation is mediated by the DNMT enzymes, which depend on the methyl donor S-adenosyl methionine (SAM). The methyl group is transferred to the $5^{\prime}$ carbon of the cytosine ring within $\mathrm{CpG}$ dinucleotides $[10,19]$. Generally, when cytosines are methylated from a $\mathrm{CpG}$ island (CpGI) of a gene, then the gene is silenced, and this CpGI is termed "hypermethylated" [20]. Normal cell differentiation requires appropriate DNA methylation/demethylation status, hypermethylation limits the capacity of cells to differentiate into cellspecific lineages and may ultimately induce a state of disease, such as tumorigenesis [21-23]. It is reported that DNA hypermethylation can silence the gene that is required for early stages of disease development; therefore, the evaluation of DNA hypermethylation may be valuable in the identification of potential biomarkers for detecting cancer early, monitoring progress, and facilitating personalized cancer therapy [24]. Moreover, the DNMT inhibitors (DNMTis) in cancer increase the immunogenicity, which inspired investigation of DNMTis in combined immunotherapy in cancer [25-27].

\section{DNA HYPERMETHYLATION IN OC}

The hypermethylated and silenced genes can induce events such as uncontrolled cell division, sustained angiogenesis, and avoided apoptosis, all of which are responsible for tumorigenesis and tumor progression $[28,29]$. As in other cancers, DNA hypermethylation in CpGIs is common in OC [30]. To date, the identification of genes that are altered by DNA methylation is an area of intense research [10]. In OC, a large number of genes undergo hypermethylation. The most common seen or the most common used genes in OC are shown in Table 1.

\section{BRCA1}

The most extensively studied gene is $B R C A 1$ (breast cancer susceptibility gene 1) due to its well-known role in inherited forms of breast and ovarian cancers [10]. BRCA1 was mapped by Mary-Claire King's group in 1990 [31] and subsequently cloned in 1994 [32]. BRCA1 encodes a protein for DNA repair mechanism, and accordingly, its hypermethylation is linked to the reduced $B R C A 1$ expression and functions $[10,33]$, which eventually results in the formation and development of breast and ovarian cancers $[34,35]$. The BRCA1 hypermethylation rate in OC is reported to be $5 \%-89.9 \%$ (Table 1 ). The histological heterogeneity of $\mathrm{OC}$ as well as differences in sample collection and processing, assay design, and detection approach may account for the variation in DNA methylation frequencies [36]. BRCA1 hypermethylation is significantly related to specific type of OC and high-grade OC $[37,38]$. The frequency of $B R C A 1$ promoter hypermethylation was markedly higher in serous OC [37]. Compared with healthy controls and stage I OC, the methylation frequencies of BRCA1 promoter were higher in stage II and III OCs [39]. Similarly, another study found that the promoter hypermethylation was in $31 \%$ of OCs and in none of the benign and borderline cases [40]. BRCA1 promoter methylation has been elucidated as a useful tool to evaluate the prognosis of OC patients as well [41]. OC patients with $B R C A 1$ promoter hypermethylation showed a significantly shorter median disease-free survival (PFS, $P=0.04$ ) and median overall survival (OS, $P=0.02$ ) compared with those harboring mutated $B R C A 1$ [42]. Of note, $B R C A 1$ promoter hypermethylation is frequently detected in sporadic OC, whereas it has not been reported in the samples from germline BRCA1 mutation cases [43, 44].

\section{MLH1}

As is well known, $M L H 1$ is an important tumor suppressor gene for DNA mismatch repair (MMR), which plays a vital role in reversing the replicative errors that escape the correction by DNA polymerases III [45]. In OC cells, chemotherapeutic agents such as carboplatin and cisplatin can damage DNA by forming intrastrand and interstrand adducts. Detection of these adducts by the MMR system leads to p53 protein phosphorylation, activation of the mitogen-activated protein kinase pathway, induction of the proapoptotic protein BAX, and finally 
Table 1: Selected genes that undergo CpG island hypermethylation in epithelial ovarian cancer

\begin{tabular}{|c|c|c|c|c|c|c|}
\hline Gene & Location & Function & $\begin{array}{l}\text { Percentage } \\
\text { Methylated }\end{array}$ & OC type & $\mathbf{N}$ & Ref \\
\hline \multirow[t]{4}{*}{ BRCA1 } & $17 \mathrm{q} 21.31$ & DNA damage repair & $15 \%$ & sporadic OC & 98 & 32 \\
\hline & & & $10 \%$ & sporadic OC & 88 & 42 \\
\hline & & & $5 \%$ & $\begin{array}{l}\text { sporadic ovarian } \\
\text { adenocarcinoma }\end{array}$ & 43 & 137 \\
\hline & & & $89.9 \%$ & EOC & 69 & 138 \\
\hline \multirow[t]{4}{*}{ MLH1 } & $3 \mathrm{p} 22.2$ & DNA mismatch repair & $9 \%$ & EOC & 234 & 36 \\
\hline & & & $30.4 \%$ & EOC & 76 & 47 \\
\hline & & & $56.3 \%$ & EOC & 36 & 48 \\
\hline & & & $37.5 \%$ & EOC & 137 & 139 \\
\hline \multirow[t]{2}{*}{ HOXА9 } & $7 \mathrm{p} 15.2$ & controlling cell growth, & $51 \%$ & EOC & 52 & 59 \\
\hline & & differentiation, proliferation & $95 \%$ & HGSOC & 92 & 61 \\
\hline \multirow[t]{4}{*}{ RASSF1A } & $3 \mathrm{p} 21.3$ & microtubulin stability & $40 \%$ & $\mathrm{OC}$ & 20 & 51 \\
\hline & & & $26.4 \%$ & stage III/IV EOC & 106 & 140 \\
\hline & & & $67.8 \%$ & $\mathrm{EOC}$ & 69 & 141 \\
\hline & & & $58 \%$ & $\mathrm{OC}$ & 119 & 142 \\
\hline \multirow[t]{3}{*}{$A P C$} & $5 q 22.2$ & $\begin{array}{l}\text { regulation of cell } \\
\text { migration and adhesion, } \\
\text { transcriptional activation } \\
\text { and apoptosis }\end{array}$ & $29 \%$ & $\mathrm{OC}$ & 119 & 142 \\
\hline & & & $22 \%$ & invasive $\mathrm{OC}$ & 69 & 143 \\
\hline & & & $47.2 \%$ & $\mathrm{OC}$ & 140 & 144 \\
\hline \multirow[t]{2}{*}{ HICl } & $17 \mathrm{p} 13.3$ & $\begin{array}{l}\text { regulation of apoptosis, } \\
\text { encoding transcriptional } \\
\text { repressor }\end{array}$ & $35 \%$ & $\begin{array}{l}\text { primary sporadic } \\
\text { OC }\end{array}$ & 88 & 42 \\
\hline & & & $17.3 \%$ & stage III/IV EOC & 106 & 140 \\
\hline$D A P K$ & $9 q 21.33$ & $\begin{array}{c}\text { regulation of apoptosis and } \\
\text { metastasis }\end{array}$ & $67 \%$ & $\mathrm{OC}$ & 32 & 145 \\
\hline$P 15$ & & cell cycle control & $64.29 \%$ & $\begin{array}{l}\text { epithelial serous } \\
\text { ovarian }\end{array}$ & 50 & 146 \\
\hline \multirow[t]{2}{*}{$P 16$} & & cell cycle control & $50 \%$ & $\begin{array}{l}\text { epithelial serous } \\
\text { ovarian }\end{array}$ & 50 & 146 \\
\hline & & & $43 \%$ & EOC & 198 & 147 \\
\hline \multirow[t]{2}{*}{ OPCML } & $11 \mathrm{q} 25$ & $\begin{array}{l}\text { signaling and growth } \\
\text { inhibition }\end{array}$ & $78.4 \%$ & $\mathrm{OC}$ & 217 & 148 \\
\hline & & & $88.1 \%$ & EOC & 46 & 149 \\
\hline CCBE1 & $18 \mathrm{q} 21.32$ & $\begin{array}{l}\text { inhibition matrix emodeling } \\
\text { and migration }\end{array}$ & $41 \%$ & $\mathrm{OC}$ & 81 & 150 \\
\hline \multicolumn{7}{|c|}{ Wnt pathway } \\
\hline \multirow[t]{2}{*}{ SFRP5 } & $10 \mathrm{q} 24.2$ & $\begin{array}{l}\text { inhibition epithelial- } \\
\text { mesenchymal transition, } \\
\text { Wnt antagonist }\end{array}$ & $44.4 \%$ & $\mathrm{OC}$ & 215 & 71 \\
\hline & & & $\begin{array}{c}\text { 64.6\%: OCCA } \\
13.3 \% \text { : OSA }\end{array}$ & OCCA, OSA & 78 & 151 \\
\hline
\end{tabular}




\begin{tabular}{|c|c|c|c|c|c|c|}
\hline $\begin{array}{l}\text { FZD4, DVL1, } \\
\text { NFATC3, } \\
\text { ROCK1, } \\
\text { LRP5, } \\
\text { AXIN1, } \\
\text { NKD1 }\end{array}$ & - & $\begin{array}{l}\text { control biological processes } \\
\text { including cell proliferation, } \\
\text { differentiation migration } \\
\text { and tissue homeostatis }\end{array}$ & $\begin{array}{c}25 \% \\
\text { (average) }\end{array}$ & EOC & 181 & 73 \\
\hline $\begin{array}{l}\text { TGF-beta } \\
\text { pathway }\end{array}$ & & & & & & \\
\hline FBXO32 & $8 \mathrm{q} 24.13$ & regulates cell apoptosis & $29.3 \%$ & advanced-stage OC & 96 & 69 \\
\hline
\end{tabular}

EOC, epithelial ovarian cancer; OC, ovarian cancer; OCCA, ovarian clear cell adenocarcinoma; OSA, ovarian serous adenocarcinoma.

apoptotic cell death [46, 47]. In the MMR-defective cells, both insertion/deletion loops and base-base mismatches are left uncorrected. Approximately $10 \%$ of OC is related to this molecular pathway [48, 49]. MLH1 promoter hypermethylation has been identified in OC cases that acquired resistance to platinum-based chemotherapy [50-52]. Hypermethylated silencing of MLH1 and the resultant reduced apoptotic response to platinum-DNA adducts are the contributing factor to platinum resistance in OC. Gifford et al. [53] investigated the prognosis of acquired resistance to chemotherapy by comparing $M L H 1$ hypermethylation status in epithelial OC (EOC) patients before and after carboplatin/taxoid chemotherapy. They discovered that hypermethylation of $M L H 1$ promoter during treatment was significantly linked to relapse and poor outcome. Another study confirmed that $\mathrm{MLHI}$ promoter hypermethylation showed a significant correlation with lymphatic metastasis $(P=0.003)$ and histological grade $(P=0.028)$ [50].

\section{RASSF1A}

Another gene found to be hypermethylated and silenced in $\mathrm{OC}$ is the gene encoding the RAS association domain family protein $1 \mathrm{a}(R A S S F 1 A)[54,55]$. RASSF $1 A$ is a vital tumor suppressor gene which can regulate cell cycle, bind to tubulin and stabilize microtubules [56]. Studies have demonstrated that RASSF1A is among the most frequently hypermethylated genes in OC $[10,57]$. To determine the potential functions of hypermethylated patterns of free-circulating DNA in patients' plasma, Liggett et al. [58] investigated the methylation patterns of cell-free plasma DNA in three cohorts (invasive EOC cases, benign ovarian cases and healthy controls). This study showed that the hypermethylation of three gene promoters (RASSF1A, CALCA, and EP300) differentiated between EOC vs. healthy control with a sensitivity of $90.0 \%$ and a specificity of $86.7 \%$. Moreover, RASSF $1 A$ and PGR-PROX promoter hypermethylation can effectively distinguish the plasma of EOC patients from benign cases, with a sensitivity of $80.0 \%$ and a specificity of $73.3 \%$. This proof-of-principle data further verify earlier findings that have demonstrated frequent
RASSF 1A promoter hypermethylation in invasive ovarian cancer but rarely in normal cases [44, 59]. Hence, it can be concluded that the frequency of RASSF $1 A$ promoter hypermethylation in $\mathrm{OC}$ establishes a potential biomarker for the presence of OC.

\section{HOXA9}

Homeobox genes belong to the family of transcription factors. They are the key genes in regulating cell growth, differentiation, and proliferation during embryonic development [60]. Studies have suggested that $\mathrm{OC}$ is related to the methylomes of $H O X$ genes [61]. Wu et al. [62] found that HOXA9 was hypermethylated in $51 \%(26 / 51)$ of ovarian carcinomas which was higher among relatively early-stage carcinomas than those of later stages $(P=0.002)$. Widschwendter et al. [63] found that HOXA9 hypermethylation was predictive of EOC formation, with an increase in $H O X A 9$ hypermethylated frequency correlating with an increase in risk of EOC. Another study demonstrated a similar result in high-grade serous OC (HGSOC) [64]. Furthermore, a combined methylation status of HOXA9 and EN1 could differentiate HGSOC from benign ovarian surface epithelium (OSE) with a sensitivity of $98.8 \%$ and a specificity of $91.7 \%$, which increased to $100 \%$ sensitivity when pre-operative CA125 levels were also incorporated [64]. These results support HOXA9 hypermethylation as a promising biomarker for detection of OC, likely in combination with other molecules and existing clinical methods [36].

\section{TGF-beta pathway}

The TGF-beta superfamily now contains around 40 secreted ligands [65], which play diverse and multifunctional roles in cell proliferation, differentiation, migration, immune response, angiogenesis and apoptosis [66]. It has been published that the hypermethylation of genes in TGF-beta signaling pathway were associated with many malignancies such as gastric [67], hepatocellular carcinoma [68], and OC [69]. In OC, the DNA hypermethylation can alter (ie, suppress) TGF-beta signaling expression [69, 70]. Kang et al. [69] found that 
TGFBI hypermethylation was detected in two OC cell lines (ES-2 and OVCAR-3) and was present in 60.5\% of OC patients, $27.8 \%$ of borderline ovarian diseases, and none of the normal cases. Furthermore, Matsumura et al. [70] conducted a microarray analysis of 39 OC cell lines and identified numerous candidate methylated genes, many relevant to TGF-beta signaling. Chou et al. [71] reported that the unmethylation of FBXO32 (TGFbeta/SMAD4 target gene and regulator of apoptosis) [72] was observed in normal OSE, but not in OC cell lines. In vitro studies have shown that the expression of FBXO32 restored sensitivity to cisplatin treatment, suggesting that $F B X O 32$ hypermethylation may act as a prognostic biomarker for EOC as well [72].

\section{Wnt pathway}

The Wnt pathway is one of the classical pathways in the process of cell signal transduction which participates in embryogenesis and cell homeostasis [73]. Several genes regulating the Wnt pathway are hypermethylated in EOC. SFRP5, a Wnt blocker, was detected methylated in $1.3 \%$ of benign ovarian cases, $21.4 \%$ borderline cases and $44.4 \%$ of EOC $(P<0.001)$ [74]. Moreover, the epigenetic silence of SFRP5 is related to malignant phenotype and chemoresistance of OC and the unmethylation of SFRP5 sensitizes OC to taxolin and cisplatin in vitro [75]. Dai et al. [76] evaluated the methylated status of 302 loci at 137 genes in Wnt signaling pathway in OC. They revealed that the increased methylation at 7 of these loci, at FZD4, DVL1, NFATC3, ROCK1, LRP5, AXIN1, and NKD1 genes was associated with increased hazard of disease progression. They also analyzed the relation between DNA methylation and patient response to platinum and found that the hypermethylated alteration of NFATC 3 and DVL1 showed significant correlation with poor response which could be independent predictors of PFS [76].

\section{CLINICAL HYPERMETHYLATED MARKERS}

As a means to detect, classify, and evaluate OC, DNA promoter hypermethylation has several advantages than other means of detection. First, the hypermethylation analysis utilizes DNA, which is more chemically stable [10]. Second, aberrant DNA methylation has a high sensitivity: it can be detected by signal amplification by sensitive polymerase chain reaction (PCR) at a low concentration in the background of excess normal DNA molecules [56]. Such detection methods include methylation-specific PCR (MSP) [77] and quantitative MSP [78]. The MethyLight and Headloop PCR are highthroughput quantitative MSP methods which are able to detect methylated alleles in the presence of up to a 100,000fold excess of unmethylated alleles [79, 80]. These methods seem promising for clinical use because of their throughput capacity and high signal-to-noise ratio [81-83]. Third, the detection of methylated biomarkers is noninvasive because they mainly exist in bodily fluids draining, serum/plasma and near a tumor [84]. Publications have demonstrated that it was feasible to detect the methylated alterations in patient's circulating DNA in a variety of tumor cells, including OC [85-87]. The clinical applications of the hypermethylated genes include early diagnosis, treatment (chemotherapy, epigenetic therapy, immunotherapy, and combined immunotherapy), and prognosis evaluation. Since we have already discussed the functions of several common genes in early diagnosis, chemotherapeutic resistance, therapeutic responsiveness, and prognosis, we will only briefly mention these similar functions and focus on epigenetic therapy, immunotherapy, and combined immunotherapy.

\section{Early diagnostic markers}

The 5-year OS rate of advanced-stage OC sharply decreases to less than $30 \%$ [4], so early diagnosis is vital for effective treatment and better prognosis. Aberrant hypermethylation is considered to be a useful biomarker for early diagnosis of OC or potentially premalignant disease because of its early appearance during tumorigenesis [22]. However, compared with the genes panel, hypermethylation of a single gene has limited practical value. Detection of multiple genes (a gene panel) simultaneously is much more sensitive and specific which can provide more information for OC diagnosis. One study reported that promoter hypermethylation was common in OC, including stage I disease, and could be readily detected using the $B R C A 1, R A S S F 1 A, A P C$, $p 14 A R F, p 16 I N K 4 a$, and $D A P K$ genes [59]. Another study reported that the multiplex MSP assay for 7 candidate genes (APC, RASSF1A, CDH1, RUNX3, TFPI2, SFRP5 and $O P C M L$ ) produced a sensitivity of $85.3 \%$ and a specificity of $90.5 \%$ in stage I OC, strikingly higher rates than that using only CA125, which produced a sensitivity of $56.1 \%$ and a specificity of $64.15 \%(P=0.0036)$ [88]. Therefore, hypermethylated biomarkers, especially gene panels, may prove more valuable for early diagnosis for OC.

\section{TREATMENT}

\section{Chemoresistance and therapeutic responsiveness}

After an initial response to first-line chemotherapy, a majority of patients with OC relapse and progress within 16-18 months due to the development of resistance to chemotherapy [2]. Apart from gene mutation, aberrant DNA hypermethylation has been recognized as a common molecular event in cancer chemoresistance [89]. Hypermethylated genes implicated in drug resistance are usually those involved in processes that affect chemosensitivity, such as DNA damage and repair 
pathways, cell cycle control, and apoptosis $[10,90]$. As aforementioned, the hypermethylation of SFRP5, a Wnt antagonist, was associated with platinum resistance in OC [75]. Similarly, the hypermethylation of other genes such as MLH1 [91], MCJ [92], HSulf-1 [93], ASS1 [94], and $D A P K$ [95] is also involved in platinum resistance. Therefore, assessing the methylation of genes is helpful in evaluating chemotherapeutic efficiency and prognosis in OC patients [96]. Moreover, combining conventional chemotherapeutic drugs with epigenetic-based therapies (inhibition the formation of hypermethylation) may provide a means to resensitize OC [96].

\section{Epigenetic therapy}

As aberrant hypermethylation is frequently observed in drug resistance, re-expression of silenced genes might allow for resensitization of drug-resistant OCs [56]. Unlike cancer-associated gene mutations, DNA hypermethylation is potentially reversible, which makes epigenetic agents that reverse methylated alterations attractive for cancer prevention and resensitization to chemotherapy. There exist 2 kinds of methylation inhibitors that have been used to re-express hypermethylation-silenced genes: nucleoside and non-nucleoside analogs. The nucleoside analogs decrease DNA methylation by incorporating themselves into DNA strands and forming covalent compound with DNMTs [97]. Non-nucleoside, the small molecule inhibitors of DNMTs, can directly incorporate into the catalytic domain of DNMTs and inhibit gene translation [98]. The first 2 DNMTis approved to treat myelodysplastic syndromes (MDSs) are azacytidine (AZA) and decitabine (2'-deoxy-5-azacytidine, DAC) $[99,100]$. AZA is a ribonucleoside that is incorporated into RNA and DNA (after conversion to the deoxyribose form) and combines to and inhibits DNMTs [101]. Treatment of chemotherapy resistant A2780 OC cell lines with 5-azacytidine resulted in re-expression of MLH1 and increased OC cells sensitivity to cisplatin [91]. DAC is another potent demethylation agent which can reverse the aberrant silencing of numerous genes in ovarian cells [102]. DAC also sensitized cisplatin-resistant OC xenografts which were $M L H 1$ silent because of gene promoter hypermethylation [103]. Two clinical trials have found that DNMTis increased the efficacy of chemotherapy for OC patients [104, 105]. Moreover, a clinical study showed that the combined application of DNMTi with carboplatin produced efficiency in platinumresistant or platinum-refractory EOC [104].

\section{Prognostic markers}

The epigenetic modifications, especially hypermethylation of genes, act as biomarkers to evaluate the prognosis for cancer patients, and several studies have assessed this for OC. For example, promoter methylation of $I G F B P-3$, which regulates the mitosis and antiapoptosis of insulin-like growth factors, was related to the disease progression and death of OC. The association was more evident in patients with early-stage disease [106]. A clinical phase III trial demonstrated that silencing of $M L H 1$ by hypermethylation of its promoter CpGI $[107,108]$ induced the relapse in EOC, with $25 \%$ of relapsed OC patients showing hypermethylated alteration of MLH1. The methylation of MLH1 at OC relapse is associated with drug resistance and predicts poor OS [53]. Wei et al. [109] found that OC patients with a short PFS (with hypermethylation) showed less sensitive to chemotherapies than those with a longer PFS (with a low methylation), indicating that higher degree of CpGI methylation facilitates chemoresistance more readily and is associated with early recurrence after chemotherapy. Therefore, the identification of a gene panel to specifically predicate and evaluate the prognosis of OC awaits validation but looks encouraging.

\section{PROMOTER HYPERMETHYLATION AND CANCER IMMUNITY}

\section{DNMTis boost tumor immunogenicity and immune response}

\section{DNMTis boost tumor major histocompatibility complex and tumor-related antigens}

As mentioned earlier, researches on hypermethylation have been increasing; however, its roles and exact mechanisms in cancer immunity are poorly understood. Immune evasion is a hallmark of tumorigenesis and development [5]. One of the most potent evasion tactics adopted by cancers is the impairment the process of antigen presentation, such as the downregulation of major histocompatibility complex (MHC) by reversibly inactivating methylation patterns $[25,110]$. DNMTi can upregulate MHC I/II and yield promising results in several cancer types such as chronic lymphocytic leukemia (CLL) [111] and acute myeloid leukemia (AML) [112]. DNMTi also upregulates immunogenicity by inducing the expression of various antigens such as cancer/testis antigens, including NY-ESO-1 [113] and SSX2 [112] and by increasing baseline expression of other molecules, such as the melanoma-associated antigens [114]. Apart from MDS and leukemia, DMNTi treatment can also increase the immunogenicity in solid tumors, especially in melanoma [115] and OC [26, 116]. It was discovered that DAC enhanced the MHC I molecules, as well as 11 cancer/testis antigen genes tested, including MAGE-A1, NY-ESO-1 and TAG-1, in OC cell lines [116].

\section{DNMTi boosts tumor immune checkpoint marker}

A study found that DNMTi reversed the repression of Th1-type chemokines CXCL9 and CXCL10, increased effector $\mathrm{T}$ cells infiltration in tumor site, and, thus, 
improved the therapeutic efficacy of adoptive T-cell transfusion and programmed death ligand 1 (PD-L1) inhibitor in mice bearing OC [27]. This study also reported that mice treated with PD-L1 checkpoint blockade or DZNep (an inhibitor of all SAM-dependent enzymes) plus DAC exerted a decreased tumor size, increased CD8+ T lymphocytes and Th1-type chemokine expression [27]. Therefore, the inhibition of DNA hypermethylation synergistically increases the therapeutic efficacy of antiPD-L1 therapy [117]. To evaluate the correlation of immune checkpoints (PD-L1, PD-L2, PD-1 and CTLA-4) with DNMTi in patients with myeloid malignancies, a study evaluated the effect of the treatment of leukemia cells with DAC and revealed that DAC leads to a dosedependent upregulation of these 4 genes [118]. During first course of DNMTi therapy, PD-L1, PD-L2, PD-1, and CTLA-4 expressions were upregulated ( $\geq 2$ fold) in $57 \%, 57 \%, 58 \%$ and $66 \%$, respectively, of patients with MDS. Moreover, when MDS patients treated with 5-AZA and vorinostat (a histone deacetylases inhibitor), there is a trend toward enhanced expression of these 4 genes in epigenetic treatment-resistant patients compared with treatment-sensitive patients [118]. This phenomenon has strong implications for the development and application of combination strategies of DNMTi with immune checkpoint inhibitors in OC [118].

\section{DNMTis stimulate natural killer cell- and CD8+ T-cell-mediated cytotoxicity}

Apart from rendering tumor cells more recognizable to $\mathrm{T}$ lymphocytes in an antigen-specific manner, the epigenetic modifiers enhance cytotoxic natural killer (NK) and CD8+ T-cell function [110]. A study found that valproic acid and DAC increased the level of MICA molecule (expressed by NK cells) and activated CD8+ T cells [119]. Moreover, DNMTi-mediated demethylation induces expression of genes involved in CTL reactivity, most notably antitumor cytokines such as interleukin-2 (IL-2). For instance, the transcription of IL-2 gene in T cells is associated with the demethylation of the promoterenhancer domain of IL-2 upon activation [110, 120]. This demethylation status was found early after CD8+ T-cell antigen exposure and is maintained throughout CD8+ T-cell memory development [121]. This indicates that IL-2 levels may be increased and maintained by DNMTimediated hypomethylation [110]. Similarly, culturing primary mouse CD8 $+\mathrm{T}$ cells with the treatment of 5-AZA increased interferon-gamma expression up to 25 -fold and IL-3 (related to T-cell growth, differentiation, and myeloid proliferation) production up to 14-fold [122]. Another study found that low-dose DAC increased the expression of antitumor chemokines released by NK cells and CD8+ T cells in the ascites of OC mice [26]. Taken together, these findings indicate the promising applications of DNMTi to increase NK and CD8+ T lymphocytes, especially via the induction or enhancement of critical immunostimulatory cytokines.

\section{DNMTi decreases immunosuppression by regulating immune cells}

Clinical outcomes reveal that the inhibition of immunosuppressive cells is equally important with activating cytotoxic NK/T cells-mediated antitumor immunity [123]. Apart from improving cancer immunogenicity and cytotoxic cells functions, DNMTi decreases natural (innate) and tumor-induced (adaptive) immunosuppression. Myeloid-derived suppressor cells (MDSCs) and regulatory $\mathrm{T}$ cells (Tregs) are vital immunosuppressive components in the immune system. In melanoma-bearing mice, the macrophage effector and dendritic cell activation increased with the low-dose of DAC treatment, while the number of MDSCs decreased [124]. Similarly, DAC decreased the percentage of MDSCs in their peritoneal cavity of murine OC model [26]. A clinical study found that the number of Tregs of 68 patients with MDS was significantly reduced following treatment with DNA methyltransferase inhibitor $[110,125]$.

\section{Rationale for combination of DNMTi with immunotherapy}

Based on the aforementioned evidence, DNMTi's great ability to prime the antitumor immunoresponse makes it a promising candidate for combinations with immunotherapies [110]. Application DNMTi alone or in combination with a histone deacetylase inhibitor to patients with MDS or AML upregulated the expression of immune checkpoint markers (CTLA-4, PD-1, PD-L1, and PD-L2), which is the prerequisite for blocking the tumor-related CTLA-4 and PD-1 pathways [120, 110]. Additionally, PD-1 [126] and CTLA-4 [127] blockades as well as DNMTis [26, 115] can elevate interferongamma production which further support the possibility of combined application of immune checkpoint blockades and DNMTi. More than $80 \%$ of the 4 T1 tumor-bearing mice were cured with the cotreatment of epigeneticmodulating drugs and checkpoint inhibitors [128]. A similar result was found in a syngeneic murine OC model on the synergistic antitumor roles of DAC with antiCTLA-4 [26]. This combination induces the differentiation of naïve $\mathrm{T}$ cells into effector $\mathrm{T}$ cells and prolongs CTL responses. Based on this encouraging evidence, multiple clinical trials applying DNMTi in combination with various immune-based therapies have been carried out [110]. A clinical trial (NCT01928576) combined 5-AZA (with or without histone deacetylase inhibitor entinostat) and checkpoint blockade (nivolumab, anti-PD-1 drug) to treat patients with non-small cell lung cancer (NSCLC). Considering the phenomenon that AZA can upregulate $P D-L 1$ gene transcripts and PD-L1 protein expression 
[129], the outlook for this clinical trial seems to be promising. The combined therapy may warrant further study and consideration for the treatment of drug-resistant OC. However, we should take the potential variables that could influence the outcome of such combinatorial therapy into account, such as the sequences of the treatment [129], the dose of DNMTis and checkpoint blockade should be used [130], the stage of tumor [131] and so on.

\section{Toxicity issue associated with DNMTis}

AZA and DAC have evidently demonstrated efficacy in hematologic malignancies such as MDS, AML and CLL, however, the use of DNMTis in solid tumors seems limited because of the low specificity, substantial toxicity, and poor bioavailability [132]. Moreover, the solid tumors patients also have DNMTis associated toxicity issue. As nucleoside analogs, AZA and DAC can be incorporated into DNA strands and act as covalent inhibitors, with low specificity and common toxic side effects, such as nausea, vomiting, diarrhea, myelosuppression, neurotoxicity, mutagenic lesions and even death [131, 133-136]. This is probably the main reason why the progress in the FDA approval of DNMTi in solid cancer is so slow. To overcome the toxicity, the non-nucleoside compounds have attracted people's attention, such as DC_517 [137], SGI-1027 [138] and RG108 [139]. In comparison with oligonucleotide derivatives, non-nucleoside molecules serve as a comparatively safer option to regulate DNMTs methylation [137-139]. Besides, clinical studies suggested that low-dose DNMTi could be a regimen for cases with refractory-advanced solid tumors $[130,131]$.

\section{CONCLUSIONS}

DNA hypermethylation is a promising and rapidly evolving area of research. The profiling of DNA hypermethylated patterns can provide new insights into their use in OC risk evaluation, early detection, personalized treatment, and prognosis. Because of its stability, sensitivity, specificity, and restriction to limited regions of DNA (ie, CpGIs) in comparison with proteins or DNA mutations, the hypermethylation status as a biomarker holds potential. However, several problems must be considered before translating OC hypermethylation into clinical practice. $\mathrm{EOC}$ is a heterogenous tumor; the frequencies of DNA methylation vary greatly for different genes and tumor types. Moreover, rather than an individual gene, a panel of gene methylations, which can increase the test's sensitivity and specificity, should be explored in the future. Furthermore, the side effects of DNMTis such as low specificity, substantial toxicity, and poor bioavailability should be taken into consideration. Although the epigenetics of OC is still in its infancy, the developments in oncologic epigenetics and immunology will move the applications of gene hypermethylation into a new territory.

\section{Author contributions}

Xinxin Zhu contributed to data collection, discussing content and writing. Jinghe Lang designed and reviewed the article.

\section{ACKNOWLEDGMENTS}

None.

\section{CONFLICTS OF INTEREST}

No potential conflicts of interest relevant to this article is reported.

\section{REFERENCES}

1. Torre LA, Bray F, Siegel RL, Ferlay J, Lortet-Tieulent J, Jemal A. Global cancer statistics, 2012. CA Cancer J Clin. 2015; 65:87-108.

2. Lavoue V, Thedrez A, Leveque J, Foucher F, Henno S, Jauffret V, Belaud-Rotureau MA, Catros V, Cabillic F. Immunity of human epithelial ovarian carcinoma: the paradigm of immune suppression in cancer. J Transl Med. 2013; $11: 147$.

3. Siegel R, Naishadham D, Jemal A. Cancer statistics, 2012. CA Cancer J Clin. 2012; 62:10-29.

4. Bast RC Jr, Hennessy B, Mills GB. The biology of ovarian cancer: new opportunities for translation. Nat Rev Cancer. 2009; 9:415-28.

5. Hanahan D, Weinberg RA. Hallmarks of cancer: the next generation. Cell. 2011; 144:646-74.

6. Baylin SB, Ohm JE. Epigenetic gene silencing in cancer a mechanism for early oncogenic pathway addiction? Nat Rev Cancer. 2006; 6:107-16.

7. Ushijima T, Asada K. Aberrant DNA methylation in contrast with mutations. Cancer Sci. 2010; 101:300-5.

8. Yoo CB, Jones PA. Epigenetic therapy of cancer: past, present and future. Nat Rev Drug Discov. 2006; 5:37-50.

9. Baylin SB, Jones PA. A decade of exploring the cancer epigenome - biological and translational implications. Nat Rev Cancer. 2011; 11:726-34.

10. Barton CA, Hacker NF, Clark SJ, O'Brien PM. DNA methylation changes in ovarian cancer: implications for early diagnosis, prognosis and treatment. Gynecol Oncol. 2008; 109:129-39.

11. Van Speybroeck L. From epigenesis to epigenetics: the case of C. H. Waddington. Ann N Y Acad Sci. 2002; 981:61-81.

12. Morgan HD, Santos F, Green K, Dean W, Reik W. Epigenetic reprogramming in mammals. Hum Mol Genet. 2005; 14:R47-58. 
13. Berger SL, Kouzarides T, Shiekhattar R, Shilatifard A. An operational definition of epigenetics. Genes Dev. 2009; 23:781-3.

14. Asadollahi R, Hyde CA, Zhong XY. Epigenetics of ovarian cancer: from the lab to the clinic. Gynecol Oncol. 2010; 118:81-7.

15. Feinberg AP, Vogelstein B. Hypomethylation distinguishes genes of some human cancers from their normal counterparts. Nature. 1983; 301:89-92.

16. Saxonov S, Berg P, Brutlag DL. A genome-wide analysis of $\mathrm{CpG}$ dinucleotides in the human genome distinguishes two distinct classes of promoters. Proc Natl Acad Sci U S A. 2006; 103:1412-7.

17. Koukoura O, Sifakis S, Spandidos DA. DNA methylation in the human placenta and fetal growth (review). Mol Med Rep. 2012; 5:883-9.

18. Clark SJ, Melki J. DNA methylation and gene silencing in cancer: which is the guilty party? Oncogene. 2002; 21:5380-7.

19. Herman JG, Baylin SB. Gene silencing in cancer in association with promoter hypermethylation. N Engl J Med. 2003; 349:2042-54.

20. Bird AP, Wolffe AP. Methylation-induced repression-belts, braces, and chromatin. Cell. 1999; 99:451-4.

21. Fisher CL, Fisher AG. Chromatin states in pluripotent, differentiated, and reprogrammed cells. Curr Opin Genet Dev. 2011; 21:140-6.

22. Jones PA, Baylin SB. The fundamental role of epigenetic events in cancer. Nat Rev Genet. 2002; 3:415-28.

23. Ehrlich M. DNA methylation in cancer: too much, but also too little. Oncogene. 2002; 21:5400-13.

24. Rishi V, Bhattacharya P, Chatterjee R, Rozenberg J, Zhao J, Glass K, Fitzgerald P, Vinson C. CpG methylation of halfCRE sequences creates C/EBPalpha binding sites that activate some tissue-specific genes. Proc Natl Acad Sci U S A. 2010; 107:20311-6.

25. Bubenik J. MHC class I down-regulation: tumour escape from immune surveillance? (review). Int J Oncol. 2004; 25:487-91.

26. Wang L, Amoozgar Z, Huang J, Saleh MH, Xing D, Orsulic S, Goldberg MS. Decitabine Enhances Lymphocyte Migration and Function and Synergizes with CTLA-4 Blockade in a Murine Ovarian Cancer Model. Cancer Immunol Res. 2015; 3:1030-41.

27. Peng D, Kryczek I, Nagarsheth N, Zhao L, Wei S, Wang W, Sun Y, Zhao E, Vatan L, Szeliga W, Kotarski J, Tarkowski R, Dou Y, et al. Epigenetic silencing of TH1-type chemokines shapes tumour immunity and immunotherapy. Nature. 2015; 527:249-53.

28. Baylin SB, Chen WY. Aberrant gene silencing in tumor progression: implications for control of cancer. Cold Spring Harb Symp Quant Biol. 2005; 70:427-33.

29. Nephew KP, Huang TH. Epigenetic gene silencing in cancer initiation and progression. Cancer Lett. 2003; 190:125-33.
30. Koukoura O, Spandidos DA, Daponte A, Sifakis S. DNA methylation profiles in ovarian cancer: implication in diagnosis and therapy (Review). Mol Med Rep. 2014; 10:3-9.

31. Hall JM, Lee MK, Newman B, Morrow JE, Anderson LA, Huey B, King MC. Linkage of early-onset familial breast cancer to chromosome 17q21. Science. 1990; 250:1684-9.

32. Miki Y, Swensen J, Shattuck-Eidens D, Futreal PA, Harshman K, Tavtigian S, Liu Q, Cochran C, Bennett LM, Ding W, Bell R, Rosenthal J, Hussey C, et al. A strong candidate for the breast and ovarian cancer susceptibility gene BRCA1. Science. 1994; 266:66-71.

33. Baldwin RL, Nemeth E, Tran H, Shvartsman H, Cass I, Narod S, Karlan BY. BRCA1 promoter region hypermethylation in ovarian carcinoma: a population-based study. Cancer Res. 2000; 60:5329-33.

34. Gudmundsdottir K, Ashworth A. The roles of BRCA1 and BRCA2 and associated proteins in the maintenance of genomic stability. Oncogene. 2006; 25:5864-74.

35. Venkitaraman AR. Cancer susceptibility and the functions of BRCA1 and BRCA2. Cell. 2002; 108:171-82.

36. Gloss BS, Samimi G. Epigenetic biomarkers in epithelial ovarian cancer. Cancer Lett. 2014; 342:257-63.

37. Yang HJ, Liu VW, Wang Y, Tsang PC, Ngan HY. Differential DNA methylation profiles in gynecological cancers and correlation with clinico-pathological data. BMC Cancer. 2006; 6:212.

38. Wiley A, Katsaros D, Chen H, Rigault de la Longrais IA, Beeghly A, Puopolo M, Singal R, Zhang Y, Amoako A, Zelterman D, Yu H. Aberrant promoter methylation of multiple genes in malignant ovarian tumors and in ovarian tumors with low malignant potential. Cancer. 2006; 107:299-308.

39. Wang YQ, Yan Q, Zhang JR, Li SD, Yang YX, Wan XP. Epigenetic inactivation of BRCA1 through promoter hypermethylation in ovarian cancer progression. J Obstet Gynaecol Res. 2013; 39:549-54.

40. Wang C, Horiuchi A, Imai T, Ohira S, Itoh K, Nikaido T, Katsuyama Y, Konishi I. Expression of BRCA1 protein in benign, borderline, and malignant epithelial ovarian neoplasms and its relationship to methylation and allelic loss of the BRCA1 gene. J Pathol. 2004; 202:215-23.

41. Weberpals JI, Tu D, Squire JA, Amin MS, Islam S, Pelletier LB, O'Brien AM, Hoskins PJ, Eisenhauer EA. Breast cancer 1 (BRCA1) protein expression as a prognostic marker in sporadic epithelial ovarian carcinoma: an NCIC CTG OV.16 correlative study. Ann Oncol. 2011; 22:2403-10.

42. Chiang JW, Karlan BY, Cass L, Baldwin RL. BRCA1 promoter methylation predicts adverse ovarian cancer prognosis. Gynecol Oncol. 2006; 101:403-10.

43. Bol GM, Suijkerbuijk KP, Bart J, Vooijs M, van der Wall E, van Diest PJ. Methylation profiles of hereditary and sporadic ovarian cancer. Histopathology. 2010; 57:363-70.

44. Rathi A, Virmani AK, Schorge JO, Elias KJ, Maruyama R, Minna JD, Mok SC, Girard L, Fishman DA, Gazdar AF. 
Methylation profiles of sporadic ovarian tumors and nonmalignant ovaries from high-risk women. Clin Cancer Res. 2002; 8:3324-31.

45. Felsberg J, Thon N, Eigenbrod S, Hentschel B, Sabel MC, Westphal M, Schackert G, Kreth FW, Pietsch T, Löffler M, Weller M, Reifenberger G, Tonn JC, et al. Promoter methylation and expression of MGMT and the DNA mismatch repair genes MLH1, MSH2, MSH6 and PMS2 in paired primary and recurrent glioblastomas. Int J Cancer. 2011; 129:659-70.

46. Siddik ZH. Cisplatin: mode of cytotoxic action and molecular basis of resistance. Oncogene. 2003; 22:7265-79.

47. Klein O, Schmidt C, Knights A, Davis ID, Chen W, Cebon J. Melanoma vaccines: developments over the past 10 years. Expert Rev Vaccines. 2011; 10:853-73.

48. Blasi MF, Ventura I, Aquilina G, Degan P, Bertario L, Bassi C, Radice P, Bignami M. A human cell-based assay to evaluate the effects of alterations in the MLH1 mismatch repair gene. Cancer Res. 2006; 66:9036-44.

49. Murphy MA, Wentzensen N. Frequency of mismatch repair deficiency in ovarian cancer: a systematic review This article is a US Government work and, as such, is in the public domain of the United States of America. Int J Cancer. 2011; 129:1914-22.

50. Zhang H, Zhang S, Cui J, Zhang A, Shen L, Yu H. Expression and promoter methylation status of mismatch repair gene hMLH1 and hMSH2 in epithelial ovarian cancer. Aust N Z J Obstet Gynaecol. 2008; 48:505-9.

51. Watanabe Y, Ueda H, Etoh T, Koike E, Fujinami N, Mitsuhashi A, Hoshiai H. A change in promoter methylation of hMLH1 is a cause of acquired resistance to platinumbased chemotherapy in epithelial ovarian cancer. Anticancer Res. 2007; 27:1449-52.

52. Brown R, Hirst GL, Gallagher WM, McIlwrath AJ, Margison GP, van der Zee AG, Anthoney DA. hMLH1 expression and cellular responses of ovarian tumour cells to treatment with cytotoxic anticancer agents. Oncogene. 1997; 15:45-52.

53. Gifford G, Paul J, Vasey PA, Kaye SB, Brown R. The acquisition of hMLH1 methylation in plasma DNA after chemotherapy predicts poor survival for ovarian cancer patients. Clin Cancer Res. 2004; 10:4420-6.

54. Yoon JH, Dammann R, Pfeifer GP. Hypermethylation of the $\mathrm{CpG}$ island of the RASSF1A gene in ovarian and renal cell carcinomas. Int J Cancer. 2001; 94:212-7.

55. Agathanggelou A, Honorio S, Macartney DP, Martinez A, Dallol A, Rader J, Fullwood P, Chauhan A, Walker R, Shaw JA, Hosoe S, Lerman MI, Minna JD, et al. Methylation associated inactivation of RASSF1A from region 3 p21.3 in lung, breast and ovarian tumours. Oncogene. 2001; 20:1509-18.

56. Maldonado L, Hoque MO. Epigenomics and ovarian carcinoma. Biomark Med. 2010; 4:543-70.
57. Ozdemir F, Altinisik J, Karateke A, Coksuer H, Buyru N. Methylation of tumor suppressor genes in ovarian cancer. Exp Ther Med. 2012; 4:1092-6.

58. Liggett TE, Melnikov A, Yi Q, Replogle C, Hu W, Rotmensch J, Kamat A, Sood AK, Levenson V. Distinctive DNA methylation patterns of cell-free plasma DNA in women with malignant ovarian tumors. Gynecol Oncol. 2011; 120:113-20.

59. Ibanez de Caceres I, Battagli C, Esteller M, Herman JG, Dulaimi E, Edelson MI, Bergman C, Ehya H, Eisenberg BL, Cairns P. Tumor cell-specific BRCA1 and RASSF1A hypermethylation in serum, plasma, and peritoneal fluid from ovarian cancer patients. Cancer Res. 2004; 64:6476-81.

60. Samuel S, Naora H. Homeobox gene expression in cancer: insights from developmental regulation and deregulation. Eur J Cancer. 2005; 41:2428-37.

61. Kelly ZL, Michael A, Butler-Manuel S, Pandha HS, Morgan RG. HOX genes in ovarian cancer. J Ovarian Res. 2011; 4:16.

62. Wu Q, Lothe RA, Ahlquist T, Silins I, Trope CG, Micci F, Nesland JM, Suo Z, Lind GE. DNA methylation profiling of ovarian carcinomas and their in vitro models identifies HOXA9, HOXB5, SCGB3A1, and CRABP1 as novel targets. Mol Cancer. 2007; 6:45.

63. Widschwendter M, Apostolidou S, Jones AA, Fourkala EO, Arora R, Pearce CL, Frasco MA, Ayhan A, Zikan M, Cibula D, Iyibozkurt CA, Yavuz E, Hauser-Kronberger C, et al. HOXA methylation in normal endometrium from premenopausal women is associated with the presence of ovarian cancer: a proof of principle study. Int $\mathrm{J}$ Cancer. 2009; 125:2214-8.

64. Montavon C, Gloss BS, Warton K, Barton CA, Statham AL, Scurry JP, Tabor B, Nguyen TV, Qu W, Samimi G, Hacker NF, Sutherland RL, Clark SJ, et al. Prognostic and diagnostic significance of DNA methylation patterns in high grade serous ovarian cancer. Gynecol Oncol. 2012; 124:582-8.

65. Bierie B, Moses HL. Tumour microenvironment: TGFbeta: the molecular Jekyll and Hyde of cancer. Nat Rev Cancer. 2006; 6:506-20.

66. Khin SS, Kitazawa R, Kondo T, Idei Y, Fujimoto M, Haraguchi R, Mori K, Kitazawa S. Epigenetic Alteration by DNA Promoter Hypermethylation of Genes Related to Transforming Growth Factor-beta (TGF-beta) Signaling in Cancer. Cancers (Basel). 2011; 3:982-93.

67. Guo W, Dong Z, Guo Y, Kuang G, Yang Z, Shan B. Concordant repression and aberrant methylation of transforming growth factor-beta signaling pathway genes occurs early in gastric cardia adenocarcinoma. Mol Biol Rep. 2012; 39:9453-62.

68. Park WS, Cho YG, Kim CJ, Song JH, Lee YS, Kim SY, Nam SW, Lee SH, Yoo NJ, Lee JY. Hypermethylation of the RUNX3 gene in hepatocellular carcinoma. Exp Mol Med. 2005; 37:276-81. 
69. Kang S, Dong SM, Park NH. Frequent promoter hypermethylation of TGFBI in epithelial ovarian cancer. Gynecol Oncol. 2010; 118:58-63.

70. Matsumura N, Huang Z, Mori S, Baba T, Fujii S, Konishi I, Iversen ES, Berchuck A, Murphy SK. Epigenetic suppression of the TGF-beta pathway revealed by transcriptome profiling in ovarian cancer. Genome Res. 2011; 21:74-82.

71. Chou JL, Su HY, Chen LY, Liao YP, Hartman-Frey C, Lai YH, Yang HW, Deatherage DE, Kuo CT, Huang YW, Yan PS, Hsiao SH, Tai CK, et al. Promoter hypermethylation of FBXO32, a novel TGF-beta/SMAD4 target gene and tumor suppressor, is associated with poor prognosis in human ovarian cancer. Lab Invest. 2010; 90:414-25.

72. Szajnik M, Czystowska-Kuzmicz M, Elishaev E, Whiteside TL. Biological markers of prognosis, response to therapy and outcome in ovarian carcinoma. Expert Rev Mol Diagn. 2016; 16:811-26.

73. Logan CY, Nusse R. The Wnt signaling pathway in development and disease. Annu Rev Cell Dev Biol. 2004; 20:781-810.

74. Su HY, Lai HC, Lin YW, Chou YC, Liu CY, Yu MH. An epigenetic marker panel for screening and prognostic prediction of ovarian cancer. Int J Cancer. 2009; 124:387-93.

75. Su HY, Lai HC, Lin YW, Liu CY, Chen CK, Chou YC, Lin SP, Lin WC, Lee HY, Yu MH. Epigenetic silencing of SFRP5 is related to malignant phenotype and chemoresistance of ovarian cancer through Wnt signaling pathway. Int J Cancer. 2010; 127:555-67.

76. Dai W, Teodoridis JM, Zeller C, Graham J, Hersey J, Flanagan JM, Stronach E, Millan DW, Siddiqui N, Paul J, Brown R. Systematic CpG islands methylation profiling of genes in the wnt pathway in epithelial ovarian cancer identifies biomarkers of progression-free survival. Clin Cancer Res. 2011; 17:4052-62.

77. Herman JG, Graff JR, Myohanen S, Nelkin BD, Baylin SB. Methylation-specific PCR: a novel PCR assay for methylation status of $\mathrm{CpG}$ islands. Proc Natl Acad Sci USA. 1996; 93:9821-6.

78. Laird PW. The power and the promise of DNA methylation markers. Nat Rev Cancer. 2003; 3:253-66.

79. Eads CA, Danenberg KD, Kawakami K, Saltz LB, Blake C, Shibata D, Danenberg PV, Laird PW. MethyLight: a highthroughput assay to measure DNA methylation.Nucleic Acids Res. 2000; 28:E32.

80. Rand KN, Ho T, Qu W, Mitchell SM, White R, Clark SJ, Molloy PL. Headloop suppression PCR and its application to selective amplification of methylated DNA sequences. Nucleic Acids Res. 2005; 33:e127.

81. Muller HM, Widschwendter A, Fiegl H, Ivarsson L, Goebel G, Perkmann E, Marth C, Widschwendter M. DNA methylation in serum of breast cancer patients: an independent prognostic marker. Cancer Res. 2003; 63:7641-5.
82. Muller HM, Oberwalder M, Fiegl H, Morandell M, Goebel G, Zitt M, Muhlthaler M, Ofner D, Margreiter R, Widschwendter M. Methylation changes in faecal DNA: a marker for colorectal cancer screening? Lancet. 2004; 363:1283-5.

83. Widschwendter M, Siegmund KD, Muller HM, Fiegl H, Marth C, Muller-Holzner E, Jones PA, Laird PW. Association of breast cancer DNA methylation profiles with hormone receptor status and response to tamoxifen. Cancer Res. 2004; 64:3807-13.

84. Cottrell SE, Laird PW. Sensitive detection of DNA methylation. Ann N Y Acad Sci. 2003; 983:120-30.

85. Hickey KP, Boyle KP, Jepps HM, Andrew AC, Buxton EJ, Burns PA. Molecular detection of tumour DNA in serum and peritoneal fluid from ovarian cancer patients. $\mathrm{Br} \mathrm{J}$ Cancer. 1999; 80:1803-8.

86. Hoque MO, Feng Q, Toure P, Dem A, Critchlow CW, Hawes SE, Wood T, Jeronimo C, Rosenbaum E, Stern J, Yu M, Trink B, Kiviat NB, et al. Detection of aberrant methylation of four genes in plasma DNA for the detection of breast cancer. J Clin Oncol. 2006; 24:4262-9.

87. Leung WK, To KF, Man EP, Chan MW, Bai AH, Hui AJ, Chan FK, Sung JJ. Quantitative detection of promoter hypermethylation in multiple genes in the serum of patients with colorectal cancer. Am J Gastroenterol. 2005; 100:2274-9.

88. Zhang Q, Hu G, Yang Q, Dong R, Xie X, Ma D, Shen K, Kong B. A multiplex methylation-specific PCR assay for the detection of early-stage ovarian cancer using cell-free serum DNA. Gynecol Oncol. 2013; 130:132-9.

89. Wilting RH, Dannenberg JH. Epigenetic mechanisms in tumorigenesis, tumor cell heterogeneity and drug resistance. Drug Resist Updat. 2012; 15:21-38.

90. Teodoridis JM, Strathdee G, Brown R. Epigenetic silencing mediated by $\mathrm{CpG}$ island methylation: potential as a therapeutic target and as a biomarker. Drug Resist Updat. 2004; 7:267-78.

91. Strathdee G, MacKean MJ, Illand M, Brown R. A role for methylation of the hMLH1 promoter in loss of hMLH1 expression and drug resistance in ovarian cancer. Oncogene. 1999; 18:2335-41.

92. Strathdee G, Vass JK, Oien KA, Siddiqui N, Curto-Garcia J, Brown R. Demethylation of the MCJ gene in stage III/IV epithelial ovarian cancer and response to chemotherapy. Gynecol Oncol. 2005; 97:898-903.

93. Lai J, Chien J, Staub J, Avula R, Greene EL, Matthews TA, Smith DI, Kaufmann SH, Roberts LR, Shridhar V. Loss of HSulf-1 up-regulates heparin-binding growth factor signaling in cancer. J Biol Chem. 2003; 278:23107-17.

94. Nicholson LJ, Smith PR, Hiller L, Szlosarek PW, Kimberley C, Sehouli J, Koensgen D, Mustea A, Schmid P, Crook T. Epigenetic silencing of argininosuccinate synthetase confers resistance to platinum-induced cell death 
but collateral sensitivity to arginine auxotrophy in ovarian cancer. Int J Cancer. 2009; 125:1454-63.

95. Lehmann U, Celikkaya G, Hasemeier B, Langer F, Kreipe H. Promoter hypermethylation of the death-associated protein kinase gene in breast cancer is associated with the invasive lobular subtype. Cancer Res. 2002; 62:6634-8.

96. Balch C, Huang TH, Brown R, Nephew KP. The epigenetics of ovarian cancer drug resistance and resensitization. Am J Obstet Gynecol. 2004; 191:1552-72.

97. Santi DV, Norment A, Garrett CE. Covalent bond formation between a DNA-cytosine methyltransferase and DNA containing 5-azacytosine. Proc Natl Acad Sci U S A. 1984; 81:6993-7.

98. Ferguson LR, Tatham AL, Lin Z, Denny WA. Epigenetic regulation of gene expression as an anticancer drug target. Curr Cancer Drug Targets. 2011; 11:199-212.

99. Jones PA, Baylin SB. The epigenomics of cancer. Cell. 2007; 128:683-92.

100. Rzepecka IK, Szafron L, Stys A, Bujko M, PlisieckaHalasa J, Madry R, Osuch B, Markowska J, Bidzinski M, Kupryjanczyk J. High frequency of allelic loss at the BRCA1 locus in ovarian cancers: clinicopathologic and molecular associations. Cancer Genet. 2012; 205:94-100.

101. Goffin J, Eisenhauer E. DNA methyltransferase inhibitorsstate of the art. Ann Oncol. 2002; 13:1699-716.

102. Takai N, Kawamata N, Walsh CS, Gery S, Desmond JC, Whittaker S, Said JW, Popoviciu LM, Jones PA, Miyakawa I, Koeffler HP. Discovery of epigenetically masked tumor suppressor genes in endometrial cancer. Mol Cancer Res. 2005; 3:261-9.

103. Plumb JA, Strathdee G, Sludden J, Kaye SB, Brown R. Reversal of drug resistance in human tumor xenografts by 2 '-deoxy-5-azacytidine-induced demethylation of the hMLH1 gene promoter. Cancer Res. 2000; 60:6039-44.

104. Fu S, Hu W, Iyer R, Kavanagh JJ, Coleman RL, Levenback CF, Sood AK, Wolf JK, Gershenson DM, Markman M, Hennessy BT, Kurzrock R, Bast RC Jr. Phase 1b-2a study to reverse platinum resistance through use of a hypomethylating agent, azacitidine, in patients with platinum-resistant or platinum-refractory epithelial ovarian cancer. Cancer. 2011; 117:1661-9.

105. Fang F, Balch C, Schilder J, Breen T, Zhang S, Shen C, Li L, Kulesavage C, Snyder AJ, Nephew KP, Matei DE. A phase 1 and pharmacodynamic study of decitabine in combination with carboplatin in patients with recurrent, platinum-resistant, epithelial ovarian cancer. Cancer. 2010; 116:4043-53.

106. Wiley A, Katsaros D, Fracchioli S, Yu H. Methylation of the insulin-like growth factor binding protein-3 gene and prognosis of epithelial ovarian cancer. Int J Gynecol Cancer. 2006; 16:210-8.

107. Strathdee G, Appleton K, Illand M, Millan DW, Sargent J, Paul J, Brown R. Primary ovarian carcinomas display multiple methylator phenotypes involving known tumor suppressor genes. Am J Pathol. 2001; 158:1121-7.

108. Geisler JP, Goodheart MJ, Sood AK, Holmes RJ, Hatterman-Zogg MA, Buller RE. Mismatch repair gene expression defects contribute to microsatellite instability in ovarian carcinoma. Cancer. 2003; 98:2199-206.

109. Wei SH, Chen CM, Strathdee G, Harnsomburana J, Shyu CR, Rahmatpanah F, Shi H, Ng SW, Yan PS, Nephew KP, Brown R, Huang TH. Methylation microarray analysis of late-stage ovarian carcinomas distinguishes progression-free survival in patients and identifies candidate epigenetic markers. Clin Cancer Res. 2002; 8:2246-52.

110. Saleh MH, Wang L, Goldberg MS. Improving cancer immunotherapy with DNA methyltransferase inhibitors. Cancer Immunol Immunother. 2016; 65:787-96.

111. Dubovsky JA, McNeel DG, Powers JJ, Gordon J, Sotomayor EM, Pinilla-Ibarz JA. Treatment of chronic lymphocytic leukemia with a hypomethylating agent induces expression of NXF2, an immunogenic cancer testis antigen. Clin Cancer Res. 2009; 15:3406-15.

112. Atanackovic D, Luetkens T, Kloth B, Fuchs G, Cao Y, Hildebrandt Y, Meyer S, Bartels K, Reinhard H, Lajmi N, Hegewisch-Becker S, Schilling G, Platzbecker U, et al. Cancer-testis antigen expression and its epigenetic modulation in acute myeloid leukemia. Am J Hematol. 2011; 86:918-22.

113. Srivastava P, Paluch BE, Matsuzaki J, James SR, Collamat-Lai G, Taverna P, Karpf AR, Griffiths EA. Immunomodulatory action of the DNA methyltransferase inhibitor SGI-110 in epithelial ovarian cancer cells and xenografts. Epigenetics. 2015; 10:237-46.

114. Tomasi TB, Magner WJ, Khan AN. Epigenetic regulation of immune escape genes in cancer. Cancer Immunol Immunother. 2006; 55:1159-84.

115. Fonsatti E, Nicolay HJ, Sigalotti L, Calabro L, Pezzani L, Colizzi F, Altomonte M, Guidoboni M, Marincola FM, Maio M. Functional up-regulation of human leukocyte antigen class I antigens expression by 5-aza-2'deoxycytidine in cutaneous melanoma: immunotherapeutic implications. Clin Cancer Res. 2007; 13:3333-8.

116. Adair SJ, Hogan KT. Treatment of ovarian cancer cell lines with 5-aza-2'-deoxycytidine upregulates the expression of cancer-testis antigens and class I major histocompatibility complex-encoded molecules. Cancer Immunol Immunother. 2009; 58:589-601.

117. Terranova-Barberio M, Thomas S, Munster PN. Epigenetic modifiers in immunotherapy: a focus on checkpoint inhibitors. Immunotherapy. 2016; 8:705-19.

118. Yang H, Bueso-Ramos C, DiNardo C, Estecio MR, Davanlou M, Geng QR, Fang Z, Nguyen M, Pierce S, Wei Y, Parmar S, Cortes J, Kantarjian H, et al. Expression of PD-L1, PD-L2, PD-1 and CTLA4 in myelodysplastic syndromes is enhanced by treatment with hypomethylating agents. Leukemia. 2014; 28:1280-8. 
119. Marbach D, Costello JC, Kuffner R, Vega NM, Prill RJ, Camacho DM, Allison KR, Kellis M, Collins JJ, Stolovitzky G. Wisdom of crowds for robust gene network inference. Nat Methods. 2012; 9:796-804.

120. Bruniquel D, Schwartz RH. Selective, stable demethylation of the interleukin-2 gene enhances transcription by an active process. Nat Immunol. 2003; 4:235-40.

121. Kersh EN, Fitzpatrick DR, Murali-Krishna K, Shires J, Speck SH, Boss JM, Ahmed R. Rapid demethylation of the IFN-gamma gene occurs in memory but not naive CD8 T cells. J Immunol. 2006; 176:4083-93.

122. Fitzpatrick DR, Shirley KM, McDonald LE, BielefeldtOhmann H, Kay GF, Kelso A. Distinct methylation of the interferon gamma (IFN-gamma) and interleukin 3 (IL-3) genes in newly activated primary CD8+ T lymphocytes: regional IFN-gamma promoter demethylation and mRNA expression are heritable in CD44(high)CD8+ T cells. J Exp Med. 1998; 188:103-17.

123. Guislain A, Gadiot J, Kaiser A, Jordanova ES, Broeks A, Sanders J, van Boven $\mathrm{H}$, de Gruijl TD, Haanen JB, Bex A, Blank CU. Sunitinib pretreatment improves tumor-infiltrating lymphocyte expansion by reduction in intratumoral content of myeloid-derived suppressor cells in human renal cell carcinoma. Cancer Immunol Immunother. 2015; 64:1241-50.

124. Triozzi PL, Aldrich W, Achberger S, Ponnazhagan S, Alcazar O, Saunthararajah Y. Differential effects of lowdose decitabine on immune effector and suppressor responses in melanoma-bearing mice. Cancer Immunol Immunother. 2012; 61:1441-50.

125. Costantini B, Kordasti SY, Kulasekararaj AG, Jiang J, Seidl T, Abellan PP, Mohamedali A, Thomas NS, Farzaneh F, Mufti GJ. The effects of 5-azacytidine on the function and number of regulatory $\mathrm{T}$ cells and T-effectors in myelodysplastic syndrome. Haematologica. 2013; 98:1196-205.

126. Peng W, Liu C, Xu C, Lou Y, Chen J, Yang Y, Yagita H, Overwijk WW, Lizee G, Radvanyi L, Hwu P. PD-1 blockade enhances T-cell migration to tumors by elevating IFN-gamma inducible chemokines. Cancer Res. 2012; 72:5209-18.

127. Paradis TJ, Floyd E, Burkwit J, Cole SH, Brunson B, Elliott E, Gilman S, Gladue RP. The anti-tumor activity of anti-CTLA-4 is mediated through its induction of IFN gamma. Cancer Immunol Immunother. 2001; 50:125-33.

128. Kim K, Skora AD, Li Z, Liu Q, Tam AJ, Blosser RL, Diaz LA Jr, Papadopoulos N, Kinzler KW, Vogelstein B, Zhou S. Eradication of metastatic mouse cancers resistant to immune checkpoint blockade by suppression of myeloid-derived cells. Proc Natl Acad Sci U S A. 2014; 111:11774-9.

129. Wrangle J, Wang W, Koch A, Easwaran H, Mohammad HP, Vendetti F, Vancriekinge W, Demeyer T, Du Z, Parsana P,
Rodgers K, Yen RW, Zahnow CA, et al. Alterations of immune response of Non-Small Cell Lung Cancer with Azacytidine. Oncotarget. 2013; 4:2067-79. http://doi. org/10.18632/oncotarget.1542.

130. Newman EM, Morgan RJ, Kummar S, Beumer JH, Blanchard MS, Ruel C, El-Khoueiry AB, Carroll MI, Hou JM, Li C, Lenz HJ, Eiseman JL, Doroshow JH. A phase I, pharmacokinetic, and pharmacodynamic evaluation of the DNA methyltransferase inhibitor 5-fluoro-2'-deoxycytidine, administered with tetrahydrouridine. Cancer Chemother Pharmacol. 2015; 75:537-46.

131. Fan H, Lu X, Wang X, Liu Y, Guo B, Zhang Y, Zhang W, Nie J, Feng K, Chen M, Zhang Y, Wang Y, Shi F, et al. Lowdose decitabine-based chemoimmunotherapy for patients with refractory advanced solid tumors: a phase I/II report. J Immunol Res. 2014; 2014:371087.

132. Xu P, Hu G, Luo C, Liang Z. DNA methyltransferase inhibitors: an updated patent review (2012-2015). Expert Opin Ther Pat. 2016; 26:1017-30.

133. Gros C, Fahy J, Halby L, Dufau I, Erdmann A, Gregoire JM, Ausseil F, Vispe S, Arimondo PB. DNA methylation inhibitors in cancer: recent and future approaches. Biochimie. 2012; 94:2280-96.

134. Stresemann C, Lyko F. Modes of action of the DNA methyltransferase inhibitors azacytidine and decitabine. Int J Cancer. 2008; 123:8-13.

135. Cowan LA, Talwar S, Yang AS. Will DNA methylation inhibitors work in solid tumors? A review of the clinical experience with azacitidine and decitabine in solid tumors. Epigenomics. 2010; 2:71-86.

136. Christman JK. 5-Azacytidine and 5-aza-2'-deoxycytidine as inhibitors of DNA methylation: mechanistic studies and their implications for cancer therapy. Oncogene. 2002; 21:5483-95.

137. Chen S, Wang Y, Zhou W, Li S, Peng J, Shi Z, Hu J, Liu YC, Ding H, Lin Y, Li L, Cheng S, Liu J, et al. Identifying novel selective non-nucleoside DNA methyltransferase 1 inhibitors through docking-based virtual screening. J Med Chem. 2014; 57:9028-41.

138. Datta J, Ghoshal K, Denny WA, Gamage SA, Brooke DG, Phiasivongsa P, Redkar S, Jacob ST. A new class of quinoline-based DNA hypomethylating agents reactivates tumor suppressor genes by blocking DNA methyltransferase 1 activity and inducing its degradation. Cancer Res. 2009; 69:4277-85.

139. Fahy J, Jeltsch A, Arimondo PB. DNA methyltransferase inhibitors in cancer: a chemical and therapeutic patent overview and selected clinical studies. Expert Opin Ther Pat. 2012; 22:1427-42. 